\title{
Creating Sustainable and Competitive Employees through the Design of Innovative Higher Education Curriculum
}

\author{
Salina Daud ${ }^{1}$, Nurazariah Abidin ${ }^{1}$, Noraina Mazuin Sapuan ${ }^{1}$ and Jegatheesan Rajadurai ${ }^{2}$ \\ ${ }^{1}$ Universiti Tenaga Nasional, Malaysia \\ ${ }^{2}$ IKIP International College Kuantan, Pahang, Malaysia
}

\begin{abstract}
The employability of graduates is dependent on their possession of relevant attributes needed in their respective industries. Therefore, this study aims to investigate the gap between the important elements of Higher Education Institutions' graduates' attributes and their actual performance when employed by industry. The dimensions of attributes and the performance of these graduates are considered in four broad areas, namely knowledge, skills, abilities and personality. Data was collected using a structured questionnaire distributed to Human Resource Managers or supervisors of the graduates in 1000 top companies in Malaysia. The results show that the graduates' performance failed to meet managers' perceptions of the importance attributes that should be possessed by these graduates. Therefore, the Higher Education Institutions should take prompt action to review the current curriculum in order to meet industry demands and market needs. The design of higher education curriculum should be directed towards incorporating attributes that are expected of the graduates and relevant to the specific industry in order to produce employable graduates. This approach will allow for effective corrective actions and the improvement of the perceived problem areas found in all four dimensions.
\end{abstract}

Keywords: Higher Education Institutions, Graduate employability, Curriculum design, Important-performance.

\section{Introduction}

As Malaysia's vision is to become a developed nation by year 2020, attention has been given to the development of human capital. Higher Education Institutions (HEIs) are the recruiting grounds for numerous industries in search of future employees. Employers often develop long term relationships with those HEIs with whom they have consistent success when recruiting young executives with the right combination of skills and personal attributes for their organizations.
However, over recent years, employers have complained that graduates from these HEIs are not able to meet employers' expectations in the current volatile and dynamic environment.

Higher education is an asset that generates considerable positive outcomes for society. Resource allocation in higher education demands that curricula be relevant and that the needs of higher education and industry be served by course offerings. Universities are urged to ensure that they produce employable graduates, able to 
compete in the employment market (Moreau \& Leathwood, 2006). Within higher education, the skills agenda has been criticized for reflecting a narrow view of educational aims and threatening academic freedom (Morley, 2001). In many countries, graduates' employability is high on the government agenda (Harvey, 2000).

In today's highly competitive job market, employers are seeking those who are highly skilled and have the appropriate academic qualifications to fill positions in an organization. Much effort has been expended by industries, the government, universities and colleges, to find solutions to these problems. Development of human capital is one of the key components prioritized in the second thrust of the Ninth Malaysian Plan. At the tertiary level of education, curriculum and teaching should be relevant to market requirements in order to avoid a mismatch of skills. Collaboration between education providers and the industries is strongly encouraged to reduce the gap between graduates' abilities and the requirements of industry (Ninth Malaysian Plan, 2006-2010).

HEIs, being the final stop before the graduates step into the world of employment, are often blamed for not preparing these future employees with the relevant skills and abilities. Recognizing their pivotal roles, HEIs have been actively involved in research and academic discussions to address the issue of unemployed graduates as well as to provide recommendations and create action plans to improve the quality of graduates that they produce.

Therefore, the objective of this study is to investigate the gap between important elements of HEIs graduates' attributes and their actual performance when they are employed in industry. The dimensions of attributes and the performance of these graduates are considered in four broad areas namely knowledge, skills, abilities and personality (KSAP).

This paper is organized as follows: Section 2 reviews previous empirical literature, Section 3 discusses on research methodology, Section 4 presents the empirical results and, Section 5 contains concluding remarks and future research.

\section{Literature Review}

Graduate employability and Industry Perspective

In the 2007 Budget speech by the Prime Minister, the number of unemployed graduates was cited as 31,000 . This figure is considered high in view of the many job vacancies advertised in the local press. The reason often proffered by prospective employers is that local graduates are viewed as being technically proficient but lacking in communication and analytical skills. This situation is not specific to local graduates. A study of unemployment problems among graduates was conducted by the National Higher Education Research Institute (2003). The study of 561 unemployed respondents suggested that the unemployed generally overrated themselves by believing that they were well qualified and met all requirements of the regular job market and attributed their unsuccessful applications to a lack of connection. The Ministry of Human Resource reported that a large number of graduates are still jobless. According to the report, $70 \%$ of graduates from public universities and Institutions of Higher Learning are still unemployed. This contrasts with $26 \%$ from Private Institutions of Higher Learning and 34\% who are foreign graduates (Suresh, 2006).

Employability of graduates is a key performance indicator for HEIs (Morley, 2001). In order to compete in the employment market, HEIs are urged to ensure that they are able to produce employable graduates that meet the needs of industry (Moreau \& Leathwood, 2006, Harvey, 2000). Therefore, many HEIs have attempted to embed skills into the curriculum (Atlay \& Harris, 2000; Chapple \& Tolley, 2000). Hillage \& Pollard (1998) stated that employability of the graduates depended on the graduates' knowledge, skills and aptitudes. Individual employability is defined as graduates being able to demonstrate attributes to obtain jobs. Commonly, institutional employability relates to the employment rates of the 
university graduates. Prior to this, Harvey \& Howard (1999), cited in Treleavan \& Voola (2008), suggested that graduate success in jobs depends more on the graduates' attributes than on narrow discipline specific degrees.

Nowadays, employers are concerned with graduates' skills which are considered more important in the recruitment process than the graduates' academic performances (Harvey, 2000). Basically, employers want a graduate who is equipped with interactive, personal (Harvey, 2000) and generic skills (Hager et al., 2002). This finding has also been supported by Purcell et al. (2002) who have revealed that for some employers, a degree may now not represent anything more than a minimum requirement, along with other evidence of suitability. According to Candy et al. (1994), HEIs have a leadership role in producing graduates with skills for continuing lifelong personal and professional development.

Nicholson \& Cushman (2000) found a difference in perception between industry participants and educators when ranking attributes for success in the retailing field. They concluded that HEIs need to be careful not to dwell on cognitive skills at the expense of affective skills such as 'leadership' and 'decision making' which may be more important for long term success in the retail field.

Trauth et al. (1993) explained that there is an "expectation gap" between industry needs and academic preparation. HEIs must work together to close this gap. Furthermore, HEIs need to place more emphasis on the integration of technologies, applications, data and business functions and less on traditional and formal system development. Meanwhile, Candy et al. (1994) found that HEIs have an important role in producing graduates who are not only attuned to the needs of the industry but who are also equipped with the skills to afford them continuing lifelong personal and professional development.
According to Raybould \& Sheedy (2005), for graduates to be attractive to employers, it is important that they are able to show evidence of having the ability to cope with uncertainty, the ability to work under pressure, demonstrate action-planning skills, communication skills, information technology skills, team work, readiness to explore and create opportunities, self confidence, self management skills and a willingness to learn.

The four main dimensions, namely knowledge, skills, abilities and other characteristics are used to look at the qualities of employees when performing their tasks (Noe et al., 2007). Knowledge refers to factual or procedural information that is necessary for successfully performing a task. Knowledge can be classified as tacit and explicit knowledge (Nonaka \& Takeuchi, 1995; Polanyi, 1966). Polanyi (1966) described tacit knowledge as knowledge that is difficult to express and is usually transferred by demonstration rather than description, while explicit knowledge is easily written down and easier to communicate and transfer between individuals. Skills refer to an individual's level of proficiency at performing a particular task or the capability to perform a job well. Skills can be divided into technical elements and behavioural elements (Noe et al, 2007). Technical elements measure "hard" technical skills while behavioural elements measure "soft" skills which include the attitudes and approaches applicants take to their work, such as the ability to collaborate on team projects. Ability refers to an individual's capacity to perform the various tasks in a job. It is a current assessment of what one can do. An individual's overall abilities are essentially made up of two sets of factors; intellectual and physical abilities (Robbins \& Judge, 2009). Intellectual abilities are those needed to perform mental activities like number aptitude, verbal comprehension, perceptual speed, inductive reasoning, deductive reasoning, spatial visualization and memory, while physical abilities are required to do tasks demanding stamina, dexterity, strength and similar characteristics. 
For "other characteristics", the discussion is focused on the Big Five Personality traits (Gibson et al., 2006; Kreitner \& Kinicki, 2008; Robbins \& Coulter, 2009; Robbins \& Judge, 2009) or Global Factors Personality (Russell \& Karol, 1994). They comprise openness, conscientiousness, extroversion, agreeableness and emotional stability. Openness is an appreciation of art, emotion, adventure, unusual ideas, curiosity, and a variety of experiences. Conscientiousness is the ability to show self-discipline, act dutifully, and to aim for achievement. It is planned rather than spontaneous behavior. Extroversion is energy, positive emotions, urgency, and the desire to seek stimulation in the company of others. Agreeableness is a tendency to be compassionate and cooperative rather than suspicious and antagonistic towards others. Emotional stability is the ability to stay calm, focused, and exhibit selfconfidence when handling stress, as opposed to insecure, anxious, and depressed reactions.

Important-Performance Analysis (IPA)

The important-performance concept is based on multi-attribute models. This technique identifies the performance of an attribute that can be changed without affecting its importance (Kitcharoen, 2004). According to Nale et al. (2000) a particular application of the technique starts with an identification of the attributes that are relevant to the situations chosen to be investigated.
This approach, also known as quadrant analysis, was introduced by Martilla \& James (1977). In their study of customer satisfaction they focused on pinpointing those quality and service elements that; a) are most important to customers and/or are likely to make the strongest contribution to overall customer satisfaction and loyalty; and b) are in need of improvement because customer evaluations of the company's performance of these elements are relatively unfavourable (i.e. customers are dissatisfied and/or perceive that the company's performance is in need of improvement). By using the central tendency measure such as mean, performance scores are ordered and classified into high or low categories, and then by pairing these two sets of rankings, each attribute is placed into one of the four quadrants that are displayed graphically using an importance-performance matrix as in Figure 1 (Eskildsen \& Kristensen, 2006). With little modification, IPA has been applied to a diverse range of contexts including hospital services (Yavas \& Shemwell, 2001), tourism management (Wade \& Eagles, 2003), education (Nale et al., 2000; O'Neill \& Palmer, 2004) and service quality (Ennew et al., 1993; Ford et al., 1999).

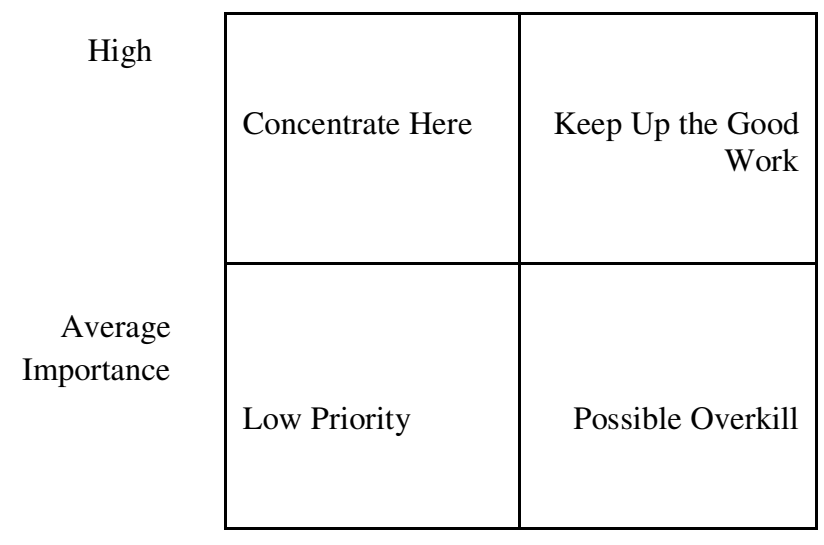

Low

Figure 1: Importance-Performance Analysis 
The IPA matrix consists of four quadrants; concentrate here, keep up the good work, low priority and possible overkill (Oliver, 1997). The explanation for each quadrant is as follows:

- Keep up the good work (High importance, high performance). These elements or attributes are assumed to be key drivers of consumer satisfaction/preference, and the management's job is to ensure that the organization continues to deliver/perform well in these areas.

- Concentrate here (High importance, low performance). These elements or attributes, also assumed to be key drivers of consumer satisfaction/preference, should be viewed as critical performance shortfalls, and the management's responsibility is to ensure that adequate resources are allocated to improve performance in these areas. These areas are priorities for improvement.

- Low priority (Low importance, low performance). These elements or attributes are assumed to be relatively unimportant, such that poor performance should not be given a great deal of priority or attention by management.

- Possible overkill (Low importance, high performance). These elements or attributes, also assumed to be relatively unimportant, should be viewed as area of performance "overkill", and management may want to redirect resources from these elements to high-priority areas in need of improved performance.

\section{Methodology}

The study was carried out in two phases. Phase 1 involved a focus group session of 10 members whose task was to obtain information from managers through a brainstorming session. This session focused on the growing concern among employers about the relevance of the HEIs curriculum in the face of developments in the real world today. The researchers, being the moderators of the focus group, sought unprompted discussion of the issues contributing to graduate unemployment in Malaysia. Using the knowledge, skills, abilities and personality (KSAP) dimensions as a basis for the study, questions were derived through the focus group interview and specific issues put forward by the group. In Phase 2, the dominant theme(s) emerging from the focus group study were used to establish a questionnaire pertaining to the KSAP dimensions.

The questionnaire was distributed personally for completion by the Human Resource Managers and supervisors of all the companies listed in the top 1000 Companies Directory. This exercise enabled the examination of the gap between the managers' perceptions of the important characteristics of graduates and their actual performance in terms of their KSAP. Pre-analysis was carried out using factor analysis and reliability analysis. Descriptive analysis was then used to describe the data. The findings were presented in the form of quadrant analysis.

\section{Instrument}

The questionnaire was divided into two sections. Section A was based on demographic profiles of the respondents while Section B measured the managers' perceptions of important characteristics and the corresponding performance of those characteristics among the graduates based on the KSAP dimensions. There were 11 factors investigated including two factors for knowledge dimensions, namely explicit and tacit knowledge, two factors for skills dimensions i.e. hard and soft skills, two factors for abilities dimensions i.e. intellectual and physical abilities and lastly, five factors for personality dimensions that consisted of conscientiousness, agreeableness, openness, extroversion, and emotional stability. The question items used to represent each factor were between 4 and 5. This is in keeping with the thoughts of Hair et al. (2006) who indicated that a minimum of 4 question items is recommended to represent a factor. The Likert scale was used to measure respondent opinions. The first attempt was to measure respondent judgements on important characteristics of graduates, 
where ' 1 ' represented extremely unimportant and ' 7 ' represent extremely important, followed by a second evaluation of the actual performance of these graduates, where ' 1 ' represented extremely bad and '7' extremely good.

\section{Sample}

The sample for the study was obtained from the 1000 top companies listed in the Malaysian Top Corporation Directory 2007-2008 which contains comprehensive information on Malaysian's top 1000 companies in a wide range of corporate and industrial sectors, ranking them in terms of financial performance and listing the leaders of the respective sectors. The respondents of this study were the Human Resource Managers and supervisors who have experienced at least one cycle of conducting a performance appraisal for his or her staff members. This was to ensure that their assessment of the graduates was comprehensive. This criterion for the

\section{Results and Discussion}

Demographic Profile

The respondents' demographic profile is presented in Table 1. 478 completed questionnaires were received representing a $48 \%$ response rate. The majority of the graduates were attached to manufacturing companies (53\%) followed by service and construction industries with $25 \%$ and $13 \%$ respectively. Most of these graduates were employed by companies located in the central region of Peninsular Malaysia (50\%). Approximately two third of the respondents in the survey were in middle management positions (64\%) and the majority of their executive staff was degree holders (45\%). Just over half of the respondents were Malay (57\%) and 65\% of them were male respondents.

Table 1: Demographic profile

\begin{tabular}{|c|c|c|c|}
\hline Items & $\%$ & Items & $\%$ \\
\hline \begin{tabular}{ll}
\multicolumn{2}{l}{ Type of industry: } \\
- & Manufacturing \\
- & Construction \\
- & Service \\
- & Information Technology \\
- & Heavy industry \\
- & Others
\end{tabular} & $\begin{array}{c}53 \\
13 \\
25 \\
3 \\
4 \\
2\end{array}$ & $\begin{array}{l}\text { Highest qualification held by } \\
\text { executive level employees: } \\
\text { - } \quad \text { Postgraduate degree } \\
\text { - } \quad \text { Degree } \\
\text { - Diploma } \\
\text { - } \quad \text { Others }\end{array}$ & $\begin{array}{c}41 \\
45 \\
12 \\
2\end{array}$ \\
\hline $\begin{array}{ll}\text { Location of company: } \\
\text { - } & \text { Northern } \\
\text { - } & \text { Southern } \\
\text { - } & \text { Central } \\
\text { - } & \text { Eastern } \\
\text { - } & \text { Western } \\
\end{array}$ & $\begin{array}{c}20 \\
16 \\
50 \\
8 \\
6\end{array}$ & \begin{tabular}{ll}
\multicolumn{2}{l}{ Highest education level: } \\
- & Postgraduate degree \\
- & Degree \\
- & Diploma \\
- & STPM/SPM \\
- & Others \\
\end{tabular} & $\begin{array}{c}19 \\
47 \\
20 \\
13 \\
1\end{array}$ \\
\hline \begin{tabular}{ll}
\multicolumn{2}{l}{ Type of company: } \\
$-\quad$ Holding/parent \\
- \\
- & Others \\
\end{tabular} & $\begin{array}{l}55 \\
10 \\
35 \\
\end{array}$ & $\begin{array}{l}\text { Number of years experience: } \\
\text { - } 1 \text { to } 5 \text { years } \\
\text { - } \quad 6 \text { to } 10 \text { years } \\
\text { - } \quad \text { More than } 10 \text { years }\end{array}$ & $\begin{array}{l}34 \\
37 \\
29\end{array}$ \\
\hline $\begin{array}{l}\text { Number of employees: } \\
\text { - } \quad \text { Less than } 20 \\
\text { - } \quad 20 \text { to } 50 \\
\text { - } \quad 51 \text { to } 150 \\
\text { - } \quad 151 \text { to } 500 \\
\text { - } \quad \text { More than500 }\end{array}$ & $\begin{array}{l}11 \\
14 \\
15 \\
18 \\
42\end{array}$ & \begin{tabular}{ll}
\multicolumn{2}{l}{ Race: } \\
- & Malay \\
- & Chinese \\
- & Indian \\
- & Others
\end{tabular} & $\begin{array}{c}57 \\
37 \\
5 \\
1\end{array}$ \\
\hline $\begin{array}{l}\text { Position at the company: } \\
\text { - } \quad \text { Top management } \\
\text { - } \quad \text { Middle management } \\
\text { - } \quad \text { Lower management } \\
\end{array}$ & $\begin{array}{l}25 \\
64 \\
11 \\
\end{array}$ & \begin{tabular}{l}
\multicolumn{2}{l}{ Gender: } \\
- $\quad$ Male \\
- $\quad$ Female
\end{tabular} & $\begin{array}{l}65 \\
35\end{array}$ \\
\hline
\end{tabular}




\section{Validity and reliability of the instruments}

The survey questions used for this study conformed to the entire validity requirement. Content validity was verified during focus group discussion. The feedback and emergent issues raised by the focus group were translated into scale items in the questionnaire. The focus group had raised a few major issues regarding graduates' attributes such as soft and hard skills, communication skills and level of confidence. The development of the graduates' attributes dimensions was based on focus groups suggestion and literature review. All necessary dimensions for graduates' attributes are included. These dimensions are also confirmed as having content validity. Factor analysis was used to establish construct validity for all the scale items of the dimensions employed in this study (Kerlinger \& Lee, 2000). All of the items in the dimensions are factor-analyzed and loaded in accordance with prior theoretical expectations. The results of the analysis of data revealed satisfactory output for further analysis.

The reliability of the data was verified using Cronbach alpha, where the closer the Cronbach alpha was to 1 , the higher the internal consistency reliability (Sekaran, 2000). The alpha coefficients for this study were all above 0.70 and were considered to be reliable (Hair et al., 2006; Nunnally, 1978). Table 2 presents the Cronbach alpha coefficient for each variable.

Table 2: Reliability statistics for importance and actual performance scale

\begin{tabular}{|l|l|c|c|c|}
\hline \multicolumn{1}{|c|}{ Dimensions } & \multicolumn{1}{|c|}{ Items } & Importance & $\begin{array}{c}\text { Actual } \\
\text { Performance }\end{array}$ & No. of item \\
\hline Knowledge & Explicit knowledge & 0.920 & 0.909 & 5 \\
\hline & Tacit knowledge & 0.914 & 0.920 & 4 \\
\hline Skills & Hard skills & 0.922 & 0.922 & 5 \\
\hline & Soft skills & 0.866 & 0.897 & 5 \\
\hline Abilities & Intellectual abilities & 0.909 & 0.915 & 5 \\
\hline & Physical abilities & 0.933 & 0.702 & 4 \\
\hline Personality & Conscientiousness & 0.919 & 0.926 & 5 \\
\hline & Agreeableness & 0.888 & 0.907 & 4 \\
\hline & Emotional stability & 0.919 & 0.918 & 4 \\
\hline & Openness & 0.914 & 0.925 & 5 \\
\hline & Extroversion & 0.924 & 0.921 & 4 \\
\hline
\end{tabular}

\section{Importance-performance analysis}

A summary of managers' importanceperformance means for 11 scale items is presented in Table 3. The negative gap values between importance-performance indicate that the graduates' performances have not met the managers' perceptions of the importance attributes that should be possessed by these graduates. In other words, graduates from the HEIs were under performing significantly in all attributes rated important by the supervisors and managers. 
Table 3: Summary of means importance and actual performance

\begin{tabular}{|l|l|c|c|c|}
\hline \multicolumn{1}{|c|}{ Dimensions } & \multicolumn{1}{|c|}{ Items } & Importance & Performance & Gap (P-I) \\
\hline Knowledge & Explicit knowledge & 6.408 & 5.633 & -0.775 \\
\hline & Tacit knowledge & 6.376 & 5.637 & -0.739 \\
\hline Skills & Hard skills & 6.400 & 5.629 & -0.771 \\
\hline & Soft skills & 6.431 & 5.623 & -0.808 \\
\hline Abilities & Intellectual abilities & 6.403 & 5.615 & -0.788 \\
\hline & Physical abilities & 6.333 & 5.662 & -0.671 \\
\hline Personality & Conscientiousness & 6.427 & 5.638 & -0.789 \\
\hline & Agreeableness & 6.343 & 5.607 & -0.736 \\
\hline & Emotional stability & 6.449 & 5.643 & -0.806 \\
\hline & Openness & 6.423 & 5.656 & -0.767 \\
\hline & Extroversion & 6.464 & 5.645 & -0.819 \\
\hline
\end{tabular}

Note: (P-I) value is significant at $\mathrm{p}<0.05$

Figure 2 presents the managers' importance-performance map. The data used to construct the importanceperformance grid was the overall means of importance and performance for all factors which were 6.41 and 5.64 respectively. Two factors fall into the "concentrate here" quadrants (high importance/low performance) which are soft skills and conscientiousness personality. The HEIs need to take immediate action on these graduates attributes. While three factors were located in the quadrant "keep up the good work" (high importance/high performance), and included extroversion personality, emotional stability personality and openness personality. The HEIs only need to maintain their current allocation of resources in developing these factors in the curriculum design of the HEIs. These three attributes are the strength attributes possessed by graduates of the HEIs in the sample, which means that graduates produced by this institution possess good personalities, in terms of extroversion, emotional stability and openness. The five attributes that fell in the "low priority" quadrant were in relation to hard skills, intellectual abilities, explicit knowledge, tacit knowledge and agreeableness personality. This indicated that these attributes did not require immediate resource allocation as they are performing at the level appropriate to the importance attached to them at the present time. However, the HEIs should hold in reserve resources to cope with a possible change of importance attached to them due to possible changes in the employment environment in the future. A physical ability is the only attribute located in the "possible overkill" quadrant. This requires the HEIs to immediately remove resources allocated to developing this attribute and redeploy the resources to developing attributes located in the "concentrate here" quadrant. The next focus is to look at items for each attribute on which the HEIs needs to take immediate action. These fall into the "concentrate here quadrant" and require a reduction in resource allocation from dimensions that are underperforming in the "possible overkill" quadrant. 


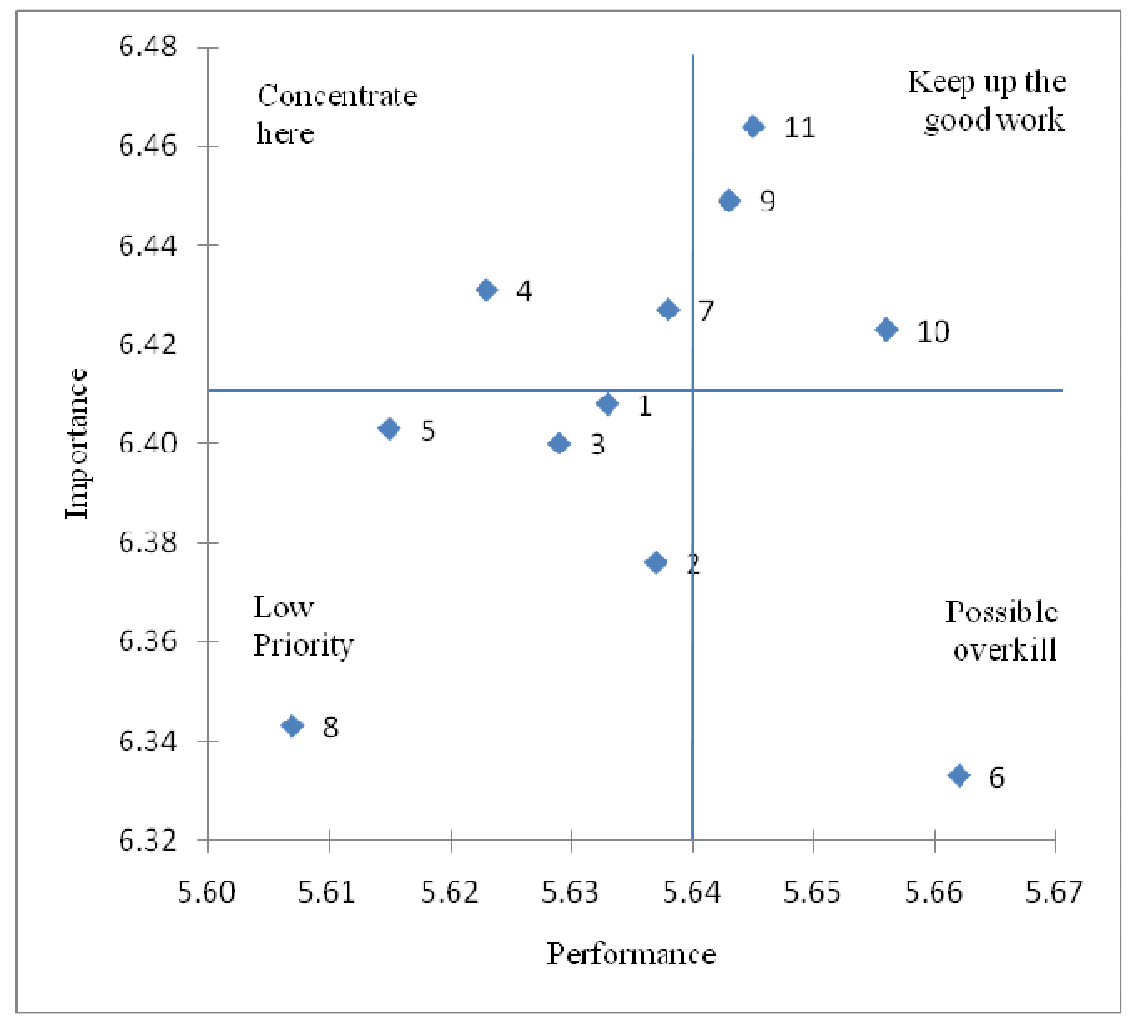

Note: 1-explicit knowledge, 2-tacit knowledge, 3-hard skills, 4-soft skills, 5-intellectual abilities, 6-physical abilities, 7-conscientiousness, 8-agreeableness, 9-emotional stability, 10-openness, 11-extroversion

Figure 2: Importance-Performance Map

\section{"Concentrate here" quadrant}

There are two factors that fall into this quadrant; soft skills and conscientiousness personality.

\section{Soft skills factor}

Soft skills are difficult to describe and intangible. An example might be a bedside manner, a pleasant voice or a cooperative spirit. Leadership, creativity and the ability to teach and learn are all considered soft skills and are the essence of what an employer is looking for in a job applicant (Stephen \& Timothy, 2007). Mean importance-performance for this factor was 6.43 and 5.62 respectively. There are five items under this factor; 1) Able to solve situational problems, 2) Present strong leadership skills, 3) Able to establish good relationship with co-workers, 4) Able to establish good relationships with top managers, and 5) Able to establish good relationships with senior staff members. Figure 3 indicates that one item fall into the "concentrate here", "keep up the good work" and "possible overkill" quadrant. Another two items fall into the "low priority" quadrant. Supervisors or managers of graduates from these HEIs are satisfied with their co-workers in terms of their ability to establish good relationships with co-workers. However, supervisors or managers commented that these graduates need to improve skills related to establishing a good relationship with their top managers. At the same time, they have reservations about the graduates' abilities in relation to maintaining a good relationship with senior staff members, and an ability to solve situational problems. These attributes may not be important at the moment, but such requisites can emerge in the future and HEIs must 
allocate resources to develop these qualities in their graduates in the future. Presenting a strong leadership skill is an item that requires the HEIs to immediately remove resources allocated in developing this attribute and redistribute the resources saved to develop attributes located in the "concentrate here" quadrant.

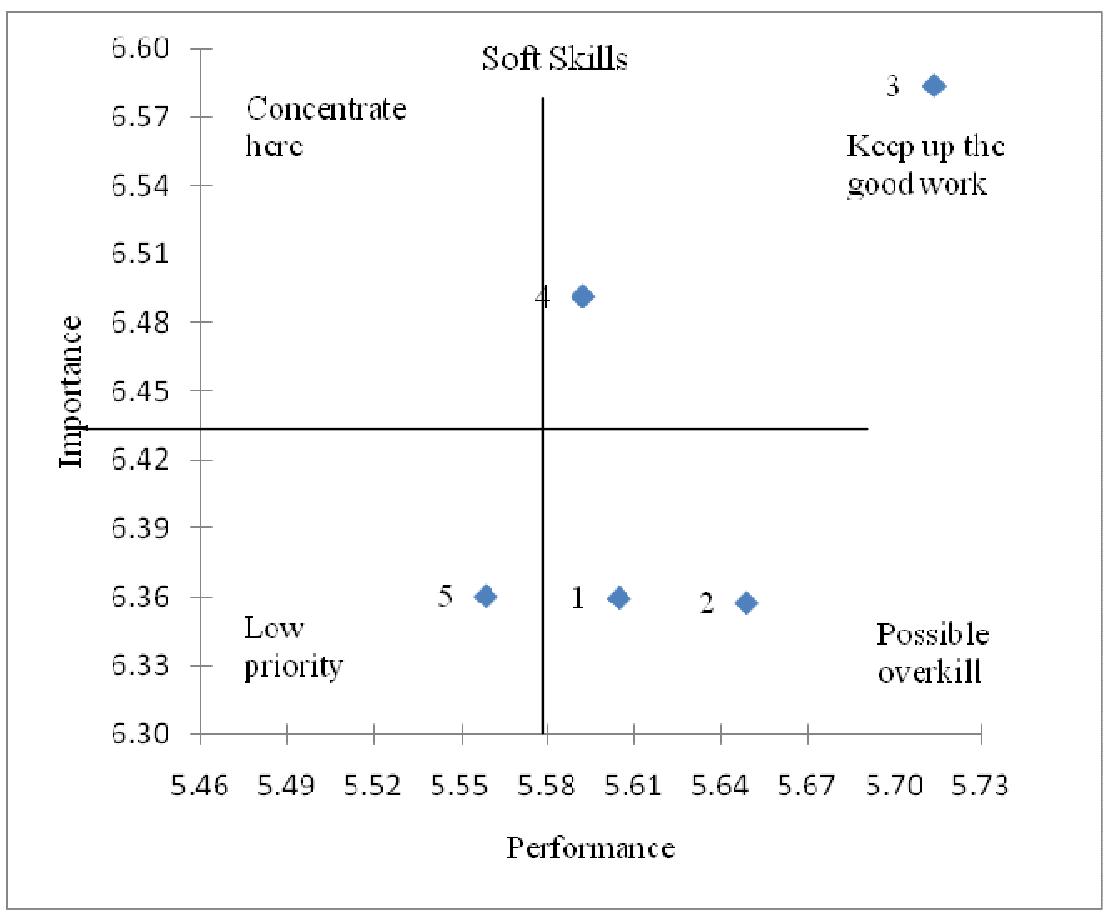

Note: 1-Able to solve situational problems, 2-Present strong leadership skills, 3-Able to establish good relationship with co-workers, 4-Able to establish good relationship with top managers, and 5-Able to establish good relationship with senior staff members

Figure 3: IPA map for soft skills factor

\section{Conscientiousness personality factor}

Conscientiousness personality is a tendency to show self-discipline, act dutifully, and to aim for achievement. This personality type is planned rather than spontaneous behaviour. Mean importanceperformance for this factor is 6.43 and 5.64 respectively. There are five items in this factor; 1) Willingness to accept responsibilities, 2) Works in an organize manner, 3) Passionate about job responsibility, 4) Ability to meet task dateline, and 5) Participates actively in the work environment. Figure 4 indicates that one item fell into the "concentrate here", "keep up the good work" and "possible overkill" quadrant. Another two items fell into the "low priority" quadrant.
Supervisors or managers of these graduates suggested that graduates from these HEIs need to organize their work systematically. Thus, HEIs need to take immediate action on these attributes when designing their curriculum. At the same time, supervisors or managers commented that these graduates were willing to accept the responsibilities given to them, which in fact, is one their strengths. In the meantime, HEIs need to remove resources allocated to develop the "Participate actively in work environment" attribute and redeploy the resources saved to develop attributes in the "concentrate here" quadrant. Finally, supervisors or managers have reservation about the graduates' abilities in relation to their passion for their job responsibilities and 
their ability to meet task datelines. These attributes may not be important at the moment, but such requisites can appear in the future and HEIs must allocate resources to develop these qualities in their graduates in the future.

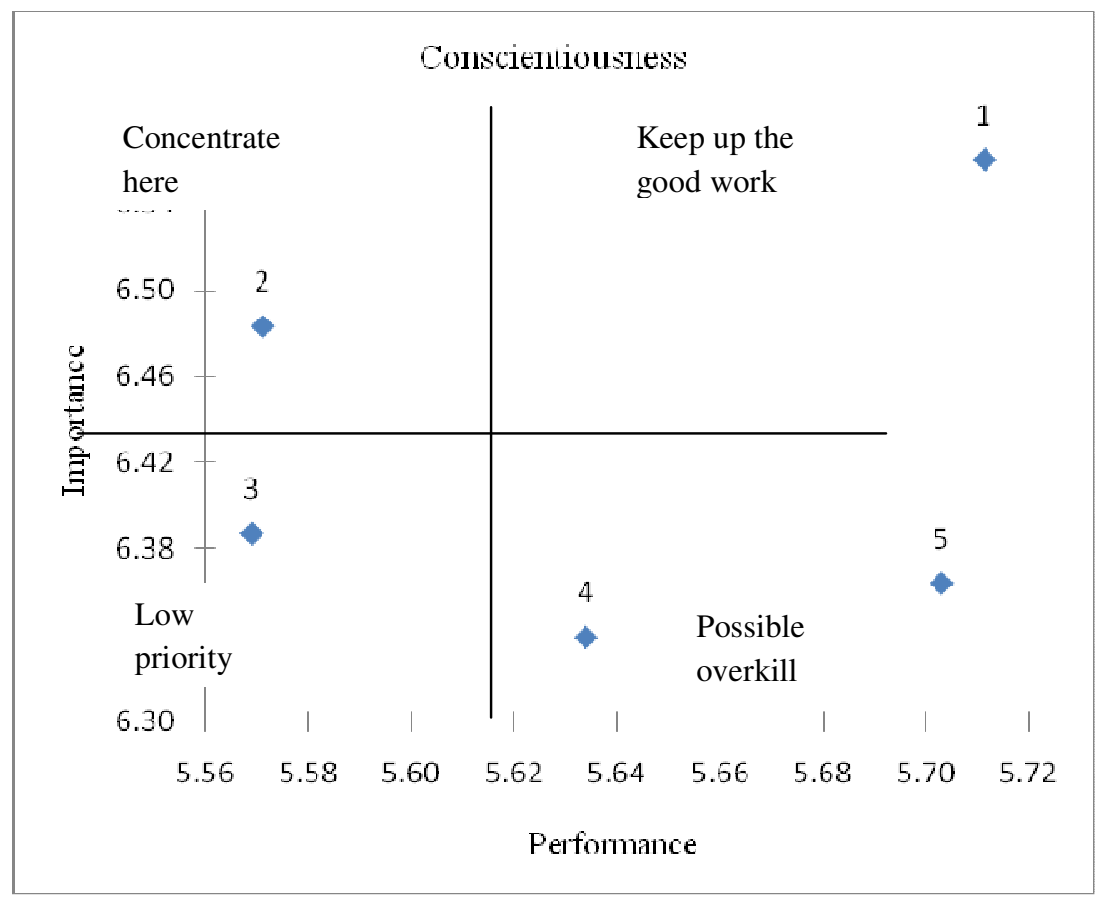

Note: 1-Willing to accept responsibilities, 2-Work in an organize manner, 3-Passionate about job responsibility, 4-Able to meet task dateline, 5-Participate actively in work environment

Figure 4: IPA map for conscientiousness personality factor

\section{"Possible overkill" quadrant}

A physical ability is the only factor that falls into this quadrant.

\section{Physical abilities factor}

Physical abilities are described as abilities that are required to do tasks that required stamina, dexterity, strength and similar characteristics. Mean importanceperformance for this factor is 6.33 and 5.66 respectively. There are four items under this factor; 1) Confronting problems effectively, 2) Ability to cope with work pressure, 3) Having strong mental endurance, and 4) Displaying a proactive disposition. Figure 5 presents these four items, where one item falls into the "concentrate here" quadrant and "possible overkill" quadrant respectively. Managers or supervisors in the samples commented that graduates need to have the ability to cope with work pressure. HEIs need to take immediate action on this attribute when designing or improving their curriculum. At the same time HEIs need to remove the resources allocated to the graduates' attribute "displaying a proactive disposition" and redeploy this resource to the "concentrate here" quadrant attribute. There are two items that neither fall into the "concentrate here" quadrant nor the "low priority" quadrant, namely the ability to confront problems effectively and having strong mental endurance. HEIs need to check these two attributes from time to time according to market demand. HEIs also need to consider the placement of these attributes when designing or updating their curriculum. 


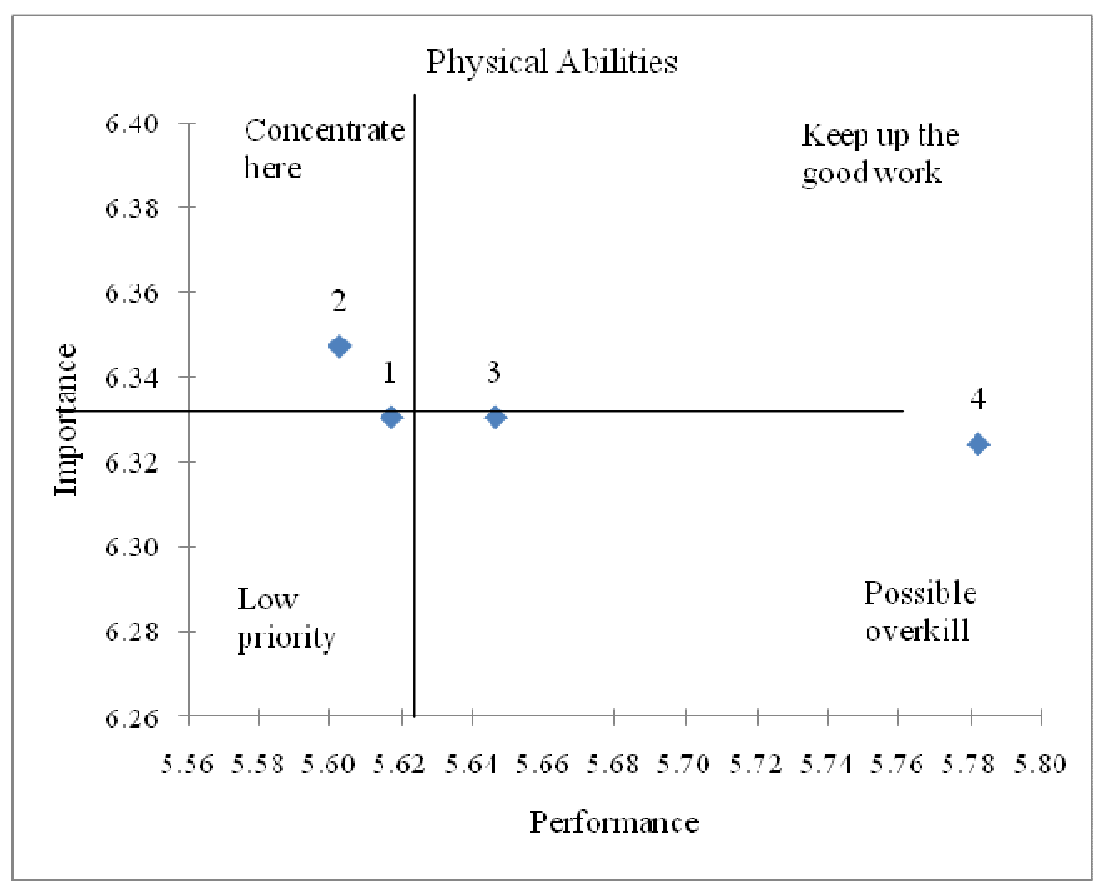

Note: 1-Confronting problems effectively, 2-Able to cope with work pressure, 3-Strong mental endurance, 4-Display a proactive disposition

Figure 5: IPA map for physical abilities factor

\section{Conclusion and Future Research}

This study has provided evidence of the usefulness of the IPA in designing curriculum development strategies for HEIs in Malaysia. The outcome of the analysis provides impetus for enhancing the quality of the higher education curriculum and making it relevant to the needs of the market and industries. The study highlights the practicality of the IPA as a means of assessing and directing continuous curriculum development efforts within the higher education sector. The use of the IPA in evaluating managers' perceptions of graduates can identify how graduates are performing, identify specific problem areas and help target corresponding improvement efforts.

The study reveals the factors relevant to the managers' perceptions of the graduates and their satisfaction level with the performance of the HEI's graduates. The results of this study indicate that managers attach different weightings to different aspects of the graduates' performance and, therefore, curriculum development efforts should be directed towards attributes that are expected of the graduates. This will allow for corrective actions which can then be taken to improve perceived problem areas. The findings of this study suggest that the HEIs in Malaysia should target improvements or inclusions of soft skills and a specific personality development component pertaining to conscientiousness in their curriculum as part of their curriculum development strategies. These HEIs should reduce their resources for enhancing physical abilities in the curriculum and maintain a low level of resource deployment in developing knowledge, hard skills, intellectual abilities and a sense of agreeableness in the manner their curriculum are administered. Clearly, these HEIs should undertake extensive employer research in order to identify those factors expected in their evaluations of graduates' performance. Consequently, 
this information can assist in decision making on a range of fronts, including facilities development, positioning attributes, curriculum development and the delivery of the core curriculum in Malaysia in the effort to produce a competitive workforce internationally.

It should be noted that this is a case study of graduates from HEIs in Malaysia. Future research could seek to establish whether a consistent pattern is observable across graduates from other HEIs in different categories of industry and the different levels of managers' expectations in other countries within the South East Asian region. It also should be noted that the quantitative analysis used does not explain why the observed ratings occurred. A supplementary exploratory study is required to address this concern. However, it must be remembered that the managers' expectations and performance ratings for specific attributes change over time due to changes in the macro environment.

\section{References}

Atlay, M. and Harris, R (2000), 'An institutional approach to developing student's transferable skills,' Innovations in Education and Training International, 37(1), 76-81.

Candy, P.C., Crebert, R.G., and O'Leary, J. (1994), 'Developing lifelong through undergraduate education,' National Board of Employment, Education and Training Commissioned, Canberra: AGPS, Report No. 28.

Chapple, M. and Tolley, H. (2000), 'Embedding key skills within a traditional university'. London: University of Nottingham -DfEE.

Ennew, C., Reed, G. and Binks, M. (1993), 'Importance-performance analysis and the measurement of service quality,' European Journal of Marketing, Vol. 27, No. 2, 59-70.

Eskildsen, J. and Kristensen, K (2006), 'Enhancing Importance-performance analysis,' International Journal of Productivity and Performance Management, Vol. 55, No. 1, 40-60.
Ford, J.B., Joseph, M. and Joseph, B. (1999) 'Importance- performance analysis as a strategic tool for service marketers: the care of service quality perceptions of business students in New Zealand and the US,' The Journal of Services Marketing, Vol. 13 No. 2, 171 - 186.

Gibson, J. L., Ivancevich, J. M., Donnelly, J. H., and Konopaske, R. (2006)., Organizations: Behavior, structure and processes, $12^{\text {th }}$ Edition. Boston, MA: McGraw-Hill.

Hager, P., Holland, S and Beckett, D. (2002), 'Enhancing the learning and employability of graduates: The role of generic skills,' Business/Higher Education Round Table, http://www.bhet.com.

Hair, J. F., Black, W. C., Babin, B. J., Anderson, R. E., \& Tatham, R. L. (2006), Multivariate data analysis, $6^{\text {th }}$ Edition. Upper Saddle-River, New Jersey: Pearson Education Inc.

Harvey, L. (2000), 'New Realities: The relationship between higher education and employment,' Tertiary Education and Management, 6, 3-17.

Hillage, J and Pollard, E. (1998), 'Employability: developing a framework for policy analysi,' Institute for Employment Studies. Retrieve from http://www.employmentstudies.co.uk/pubs/summary.php?id=empl blty\&style=print.

Kerlinger, F. N., \& Lee, H. B. (2000). Foundations of behavioural research. Fourth Edition. New York, Wadsworth: Thomson Learning.

Kitcharoen, K (2004), 'The importanceperformance analysis of service quality in administrative departments of private universities in Thailand,' $A B A C$ Journal, Vol. (24), No. 3, 20-46.

Kreitner, R. and Kinicki, A. (2008), Organizational behaviour, $8^{\text {th }}$ Edition. Boston, MA: McGraw-Hill. 
Malaysia Top Corporation Directory 20072008. Kuala Lumpur, Malaysia: Basis Publications House Sdn Bhd.

Martilla, J. A. and James, J.C. (1977), 'Importance-performance analysis,' Journal of Marketing, Vol. 41, No. 1, pp. 77-99.

Moreau, M. and Leathwood, C. (2006), 'Graduates employment and the discourse of employability: a critical analysis,' Journal of Education and Work. Vol. 19, No. 4, September 2006, 305-324.

Morley, L. (2001), 'Producing new workers: quality, equality and employability in higher education,' Quality in Higher Education, Vol. 7, No. 2,131-138.

Nale, R., Rauch, D., Wathen, S. and Barr, P. (2000), 'An exploratory look at the use of importance-performance analysis as a curricular assessment tool in a school of business,' Journal of Workplace Learning: Employee Counselling Today, Vol. 12, No. 4, 139-145.

National Higher Education Research Institute (2003), Psychological attributes of graduates. Bulletin of Higher Education Research, 1, 3-5.

Nicholson, A. and Cushman, L. (2000), 'Developing successful employees: perceptions of industry leaders and academicians,' Education and Training, Vol. 42, No. 6, 366-371.

Ninth Malaysian Plan 2006-2010, Report Economic Planning Unit. Malaysia

Noe, R.A, Hollenbeck, J.R. and Gerhart, B (2007), Fundamental of Human Resource Management. New York: McGraw-Hill.

Nonaka, I. and Takeuchi, H. (1995), The Knowledge-Creating Company. How Japanese Companies Create the Dynamics of Innovation. Oxford: Oxford University Press.

Nunnally, J. C. (1978). Psychometric theory. Second Edition. Boston, MA: McGraw Hill.

Oliver, R.L. (1997). Satisfaction. Boston, MA: McGraw-Hill,
O'Neill, M. and Palmer, A. (2004), 'Importance-performance analysis: a useful tool for directing continuous quality improvement in higher education,' Quality Assurance in Education, Vol. 12, No. 1, 3952.

Polanyi, M. (1966), The Tacit Dimension. London, UK: Routledge and Kegan Paul.

Purcell, K., Morley, M. and Rowley, G. (2002), 'Employers in the New Graduate Labour Market: Recruiting from a wider spectrum of graduate,' Employment Studies Research Unit. London: CIHE-ESRU.

Raybould and Sheedy (2005), 'Are graduates equipped with the right skills in the employability stakes?' Industrial and Commercial Training. Vol. 37, No. 5, 259263.

Robbins, S. P. and Coulter, M. (2009). Management, $10^{\text {th }}$ Edition. Upper SaddleRiver, New Jersey: Pearson Education Inc.

Robbins, S. P. and Judge, T. A. (2009). Organizational Behaviour, 13 ${ }^{\text {th }}$ Edition. Upper Saddle-River, New Jersey: Pearson Education Inc.

Russell, M.T., and Karol, D. (1994). 16PF Fifth Edition Administrator's manual Champaign. IL: Institute for Personality \& Ability Testing.

Sekaran, U. (2000), Research methods for business: A skill-building approach. USA: John Wiley and Sons, Incorporation.

Stephen. P.R and Timothy A. J. (2007). Organizational Behaviour. Upper SaddleRiver, New Jersey: Pearson Education Inc.

Suresh, R. (2006), 70\% of grads from public institutions jobless. http://www.sun2surf.com/article.cfm?id= 14660

Trauth, E., Farwell, D. and Lee, D. (1993), 'The IS expectation gap: Industry expectation versus academia preparation,' MIS Quarterly, Vol. 17, No. 3, 293-307. 
Treleavan, L. and Voola, R. (2008), 'Integrating the Development of Graduate Attributes Through Constructive Alignment,' Journal of Marketing Education, Vol. 30, No. 2, 160- 173.

Wade, D. and Eagles, P. (2003), 'The use of importance-performance analysis and market segmentation for tourism management in parks and protected areas: an application to Tanzania's National Parks,' Journal of Ecotourism, Vol. 2, No. 3, 196-212.

Yavas, U. and Shemwell, D. (2001), 'Modified Importance-Performance Analysis: An Application to Hospitals,' International Journal Health Care Quality Assurance, Vol. 14, Issue 3, pp. 104-110. 